\title{
Approaches adopted by dentists for management of occlusal caries in primary teeth
}

\section{Condutas adotadas por cirurgiões-dentistas frente à cárie oclusal em dentes decíduos}

\author{
Julianna Larissa de Sousa SANTOS' \\ Matheus de França PERAZZO² \\ Gustavo Leite RIBEIRO² \\ Ramon Targino FIRMINO2 \\ Ana Flávia Granville-GARCIA² \\ Jainara Maria Soares FERREIRA ${ }^{1}$
}

\section{ABSTRACT}

\section{Objective}

To evaluate the approaches used by Family Health Strategy dentists in the city of Campina Grande, Paraiba, Brazil, for management of occlusal caries in primary teeth.

\section{Methods}

In this observational, cross-sectional, census-based, descriptive study, 33 professionals completed a questionnaire designed to evaluate their approach to management of occlusal caries in enamel and dentin of deciduous teeth in different risk situations. Data were analyzed through descriptive and inferential statistics (Fisher's exact test with the level of significance set to 5\%). Inter-examiner agreement was evaluated by Cohen's kappa statistic.

\section{Results}

For chronic enamel caries in primary teeth with low risk/activity, the approach of choice was preventive, with fluoride application being the most cited intervention (39.3\%). For active carious dentin in primary teeth with high risk/activity and with low risk/activity, invasive approaches were most prevalent (93.9\% and $78.8 \%$, respectively), with complete caries removal (74.2\%) and glass-ionomer restoration (69.2\%) being the most frequent responses. Inter-examiner agreement was moderate $(k=0.44)$.

\section{Conclusion}

Although a wide range of approaches were adopted by dental practitioners, most preferred invasive interventions, even in situations where preservation of tooth structure was recommended.

Indexing terms: Dental caries. Practice patterns, dentists. Tooth, deciduous.

\section{RESUMO}

\section{Objetivo}

Avaliar a conduta de cirurgiões-dentistas da Estratégia de Saúde da Família do município de Campina Grande, Paraíba, Brasil, frente à cárie oclusal em dentes decíduos.

\section{Métodos}

Foi um estudo observacional, transversal, censitário e descritivo no qual 33 profissionais responderam a um questionário que avaliou suas condutas diante de cáries oclusais em esmalte e dentina de dentes decíduos, em diferentes situações de risco. Os dados foram analisados por meio de estatística descritiva e inferencial (Teste Exato de Fisher com nível de significância de 5\%). A concordância inter-examinador foi avaliada pelo Teste Kappa de Cohen.

\section{Resultados}

Para a cárie crônica em esmalte de dentes decíduos com baixo risco/atividade de cárie a conduta de eleição foi preventiva, sendo a aplicação de flúor a mais citada (39,3\%). Nos casos de cárie ativa em dentina em dentes decíduos com alto risco/atividade de cárie e de cárie ativa em dentina de dentes decíduos com baixo risco/atividade de cárie, a conduta invasiva foi a mais indicada (93,9\% e 78,8\%, respectivamente), sendo a remoção total do tecido cariado $(74,2 \%)$ e restauração com ionômero de vidro $(69,2 \%)$ as respostas mais frequentes. A concordância inter-examinador foi moderada $(k=0,44)$.

\section{Conclusão}

As condutas adotadas pelos profissionais variaram bastante, havendo uma preferência por condutas caráter invasivo em situações onde a preservação da estrutura dentária era o mais indicado.

Termos de indexação: Cárie dentária. Condutas na prática dos dentistas. Dente decíduo.

\footnotetext{
${ }^{1}$ Centro Universitário de João Pessoa, Departamento de Odontologia. BR 230, Km 22, Água Fria, 58053-000, João Pessoa, PB, Brasil. Correspondência para / Correspondence to: JMS FERREIRA. E-mail: <jainara.sf@gmail.com>.

${ }^{2}$ Universidade Estadual da Paraíba, Departamento de Odontologia. Campina Grande, PB, Brasil.
} 


\section{INTRODUCTION}

With increasing scientific and technological development in dentistry, new strategies are being employed with the goal of maximal conservation and minimal intervention in dental tissues affected by carious lesions ${ }^{1}$. The optimal limits of carious tissue removal and the possibility of ever less invasive methods to arrest and control the development of caries are being discussed in the literature ${ }^{2-9}$.

The many possibilities for invasive or conservative treatment of dental caries at its various stages are a source of doubt among dental practitioners as to which clinical approach should be adopted; as no scientific consensus has been reached, there is no one standard of care to follow ${ }^{10}$. These doubts, associated with the risks of false-positive and false-negative diagnoses, may lead to adoption of irreversibly invasive treatment approaches, particularly when treating primary teeth, the tissues of which are less mineralized and thinner than those of permanent teeth ${ }^{11}$.

The Brazilian municipality of Campina Grande, state of Paraíba, has 49 oral health teams working within the framework of the Family Health Strategy (Estratégia de Saúde da Familia, ESF). According to the Brazilian Ministry of Health's Department of Primary Care, these teams cover a population of approximately 341,550 . Within this context, the present study sought to assess the approaches adopted by primary care dentists in this municipality when faced with carious lesions in the primary dentition. The objective was to ascertain whether these practitioners adopt the tenets of minimally invasive dentistry in their clinical practice.

\section{METHODS}

This cross-sectional, observational, census-based, descriptive study was conducted at all Family Health Strategy units in the municipality of Campina Grande that have oral health teams. As noted, this municipality currently has 49 ESF-affiliated dentists. All dentists working at ESF units in Campina Grande who agreed to take part in the study and provided written informed consent were eligible for participation.

On the basis of previous studies ${ }^{1,10}$, data were collected using a questionnaire consisting of three closedended questions, each of which presented a case vignette of carious lesions in primary teeth, at different disease stages and different levels of risk for the development of new lesions. Respondents were asked which approach they would adopt (no treatment, preventive procedures, or curative procedures) in each case. These clinical cases were presented exclusively as written vignettes. No clinical or radiographic images that could serve as diagnostic aids were provided. The questionnaires were delivered to the professionals, who completed the instruments in a separate room, outside the presence of the investigator. No additional information on the cases was provided other than that contained in the vignettes themselves. Data collection took approximately 15 minutes, so as to minimize disruption of the respondents' occupational activities. Information on age, number of years in practice, and postgraduate education was also collected.

Before data collection, a pilot study was conducted with $10 \%$ of the sample $(n=4)$ to assess comprehension of the instrument; this was deemed satisfactory, and no changes were necessary. The test-retest reliability of the instrument was also assessed, with a 7-day interval between administrations. The agreement between tests was $80 \%$.

Data were analyzed in IBM SPSS Statistics for Windows, Version 21.0 (IBM Corp, Armonk, NY, USA, 2012) by means of descriptive and inferential statistics. Fisher's exact test was used to ascertain whether associations existed among time since graduation, educational level, and clinical approaches. The significance level was set at $5 \%$. Cohen's kappa test was used to evaluate agreement in treatment decisions ${ }^{12}$

The present study was approved by the Centro Universitário de João Pessoa Research Ethics Committee (opinion no. 411,136), and was conducted in accordance with Brazilian National Health Council Resolution no. 466 of 2012 and with the principles set forth in the Declaration of Helsinki (2000).

\section{RESULTS}

Thirty-three dentists participated in the study. Sixteen did not participate due to absence from occupational activities (vacation or sick leave) or failure to locate them at the health centers after three attempts. The respondents were predominantly female (75.8\%). Most were aged 51 or older (39.4\%), had been practicing for more than 10 years (87.9\%), and had a postgraduate education (90.9\%) (Table 1). Management approaches were not associated with time since graduation or educational level $(p>0.05)$. 
Table 1. Sample profile. Campina Grande, PB, Brazil (2014).

\begin{tabular}{|c|c|c|}
\hline Variable & $\mathbf{n}$ & $\%$ \\
\hline \multicolumn{3}{|l|}{ Sex } \\
\hline Male & 8 & 24.2 \\
\hline \multicolumn{3}{|l|}{ Age Group } \\
\hline 40 years or younger & 9 & 27.3 \\
\hline \multicolumn{3}{|c|}{ Time since Graduation } \\
\hline$\leq 10$ years & 4 & 12.1 \\
\hline$>10$ years & 29 & 87.9 \\
\hline \multicolumn{3}{|c|}{ Educational Attainment } \\
\hline Undergraduate & 3 & 9.1 \\
\hline
\end{tabular}

The first vignette presented to the respondents consisted of a case of chronic enamel caries in a patient with no pain and no abnormalities on periapical radiographs. In this case, most respondents chose a preventive approach
(84.8\%), predominantly consisting of topical fluoride application (39.3\%). Among invasive approaches, complete caries removal $(80.0 \%)$ and glass ionomer restoration $(60.0 \%)$ were the most commonly cited procedures (Table 2 ).

Table 2. Approaches for management of chronic enamel caries in primary teeth in a patient with low disease activity and low risk of new carious lesions. Campina Grande, PB, Brazil (2014).

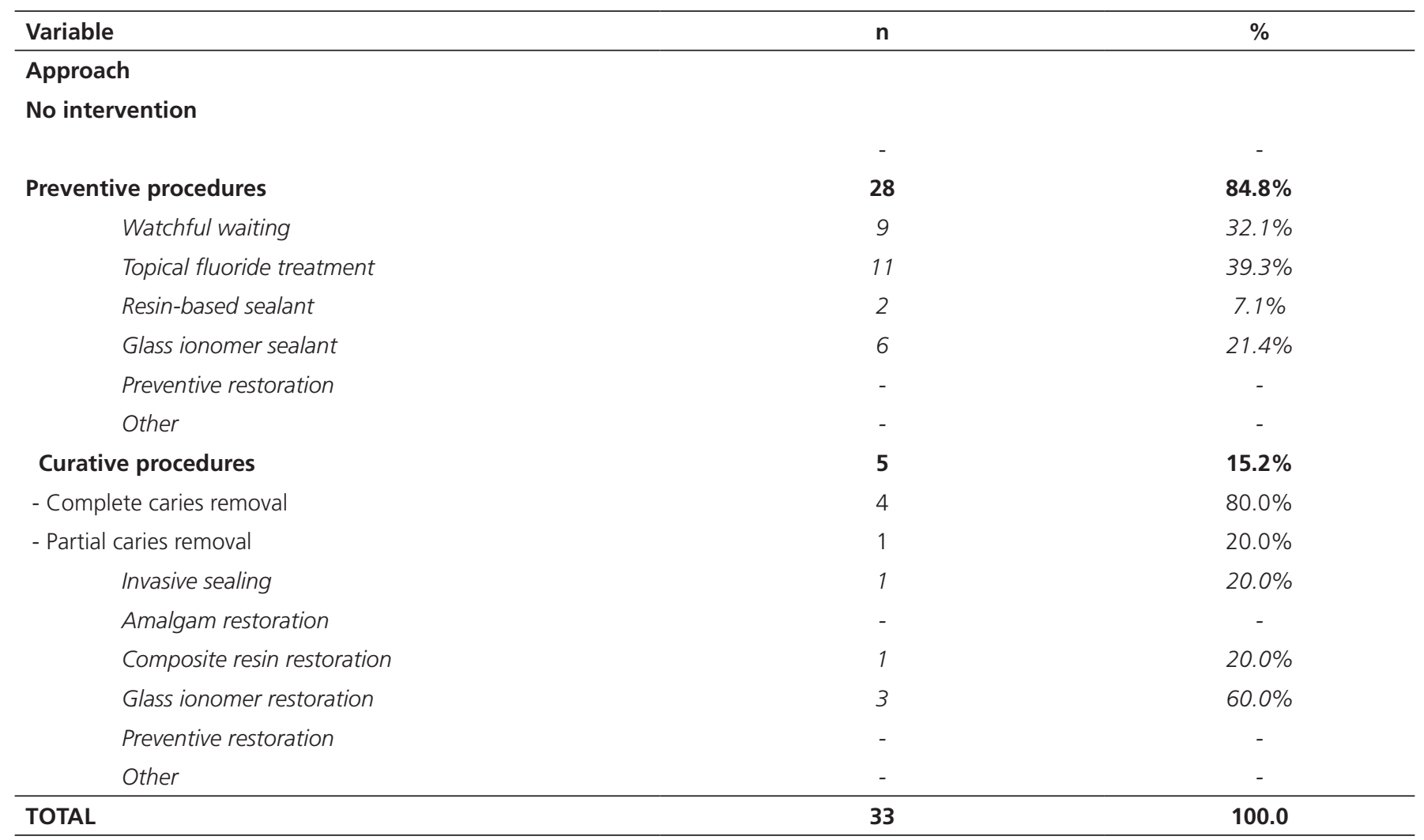


When presented with a case vignette of active carious dentin in primary teeth in a patient with high disease activity and high risk of developing new carious lesions, most respondents proposed curative procedures (93.9\%), with particular emphasis on complete caries removal $(74.2 \%)$ followed by glass ionomer restoration (51.6\%) (Table 3).

Table 3. Approaches for management of active carious dentin in primary teeth in a patient with high disease activity and high risk of new carious lesions. Campina Grande, PB, Brazil (2014).

\begin{tabular}{|c|c|c|}
\hline Variable & $\mathrm{n}$ & $\%$ \\
\hline \multicolumn{3}{|l|}{ Approach } \\
\hline \multicolumn{3}{|l|}{ No intervention } \\
\hline & - & - \\
\hline Preventive procedures & 2 & $6.1 \%$ \\
\hline Watchful waiting & - & - \\
\hline Topical fluoride treatment & - & - \\
\hline Resin-based sealant & 1 & $50.0 \%$ \\
\hline Glass ionomer sealant & - & - \\
\hline Preventive restoration & - & - \\
\hline Other & 1 & $50.0 \%$ \\
\hline Curative procedures & 31 & $93.9 \%$ \\
\hline - Complete caries removal* & 23 & $74.2 \%$ \\
\hline - Partial caries removal* & 4 & $12.9 \%$ \\
\hline Invasive sealing & 1 & $3.2 \%$ \\
\hline Amalgam restoration & 10 & $32.2 \%$ \\
\hline Composite resin restoration & - & - \\
\hline Glass ionomer restoration & 16 & $51.6 \%$ \\
\hline Preventive restoration & 4 & $12.9 \%$ \\
\hline Other & - & - \\
\hline TOTAL & 33 & 100.0 \\
\hline
\end{tabular}

\footnotetext{
* Four participants did not answer this item.
}

When presented with a case of active carious dentin in primary teeth in a patient with low disease activity and low risk of developing new carious lesions, most respondents again proposed curative procedures (78.8\%), namely, complete caries removal $(73.1 \%)$ followed by glass ionomer restoration (69.2\%) (Table 4). For assessment of inter-examiner agreement, the approaches proposed by the respondents were compared to the tenets of contemporary minimally invasive dentistry (considered the gold standard). This comparison yielded $k=0.44$, which denotes moderate agreement ${ }^{12}$.

\section{DISCUSSION}

Scientific evidence shows that minimal intervention is a viable alternative for treatment of dental caries in public health settings. In this minimally invasive treatment modality, only those dentin tissues infected by the cariogenic pathogens that cause disease progression are removed; deeper affected dentin, which is amenable to remineralization, is preserved ${ }^{5,7-9}$. To ensure maximum prevention of healthy tissue loss, carious lesions must be diagnosed in the early stages of enamel and dentin involvement, when procedures can still be adopted to 
arrest caries progression and achieve clinical control. At more advanced stages, minimally invasive procedures can be performed ${ }^{6}$.

From this perspective, the present study sought to investigate the approaches adopted by Family Health Strategy dentists at a large city in Northeast Brazil for management of dental caries in primary molars, at different stages and levels of disease activity. The objective was to ascertain whether these practitioners adopt the tenets of minimally invasive dentistry in their clinical practice.

The first case vignette presented described a case of chronic caries with minimal tooth structure loss, restricted to inner portion of enamel, with no periapical lesions and no pain, in a patient with good dietary and oral hygiene habits. In this scenario, as in a previous study $^{13}$, most respondents reported they would choose a preventive approach, with particular emphasis on topical fluoride treatment. Such management is considered appropriate for the presented case.

Nevertheless, more than 15\% of respondents would have performed invasive procedures, especially complete caries removal. These procedures cause major loss of healthy tissue and should be replaced by approaches designed to conserve tooth structure, whereby incipient enamel and dentin lesions are not removed, but instead are treated to arrest and control caries progression. At more advanced stages, minimally invasive procedures that preserve tooth structure can still be used, alongside educational and health promotion interventions, with a view to treating the disease of dental caries rather than simply restoring carious lesions ${ }^{9,14}$.

Stepwise excavation (removal of carious tissue in two stages) and, more recently, single-visit partial caries removal are alternative management strategies that can be used to control dental caries in cases of deep dentin involvement, due to the potential for remineralization and cure of the dentin-pulp complex ${ }^{4,7,15-18}$. Within this context, the second vignette presented to respondents consisted of a case of active caries affecting the inner dentin layer, with substantial tooth structure loss, in a patient with sugar sensitivity, a carbohydrate-rich diet, and deficient oral hygiene. As in a previous report ${ }^{17}$, respondents predominantly chose invasive procedures for this case, especially complete caries removal. However, the gold-standard treatment for such a case would be partial caries removal. Currently, there is no evidence to justify complete caries removal even in cases of infected dentin; partial removal is always preferable, as complete removal entails a risk of pulp exposure , $^{98-19}$.

The last vignette presented was a case of active dental caries, restricted to the outer dentin layer, in a patient with no tooth sensitivity, a satisfactory diet, and good oral hygiene. In this case, most respondents reported they would adopt curative procedures, particularly complete caries removal; again, this would constitute inappropriate management. From a public health standpoint, pit-and-fissure sealants provide a noninvasive alternative for control of some of the etiologic agents of dental caries, by acting as a mechanical barrier between the pathogenic biofilm and the tooth structure $^{20}$. Systematic reviews of the literature support this method as a preventive and therapeutic alternative to arrest the development of carious lesions ${ }^{21-24}$. The purpose of sealing dental caries is to control the disease. Thus, it would be the treatment of choice for the case vignette presented, as it enables maximal preservation of tooth structure while arresting the decay process, by limiting the substrate needed for bacterial growth in the remaining dentin.

Another aspect assessed in the present study was the agreement between respondents' choices and the tenets of minimally invasive dentistry, which is considered the gold standard of therapy. By crossreferencing the responses of all 33 participants against the gold standard, we obtained a mean kappa value of 0.44 , which denotes moderate agreement ${ }^{12}$. Divergences in management approaches between professionals have been commonly reported in the literature ${ }^{1,10}$, and probably occur because diagnosis of dental caries is still a point of substantial disagreement among dentists ${ }^{25}$. The multiple treatment protocols taught at different dental schools may also explain the differences in procedures adopted by the participants of this study.

Except in the first case vignette, respondents predominantly chose invasive approaches in situations where conservation of tooth structure was recommended. A similar trend has been reported in other studies of the same topic, but in the permanent dentition ${ }^{1,10}$. This finding demonstrates that respondents' practices are outdated when it comes to minimally invasive procedures, and reveals a need for continuing education among primary health care professionals. Targeted efforts at establishing more flexible work hours, or even provision of financial incentives by the State, are potential alternatives for the achievement of this goal. 
One limitation of our study was the absence of information on respondents' approaches to management of active enamel caries. We suggest that further studies be conducted to investigate this scenario, as minimally invasive approaches are the cornerstone of prevention and control of the carious process in primary teeth in these cases. In addition, the small number of studies designed to evaluate dentists' practices for management of caries in primary teeth prevented comparison of our results to those of other authors. Another limitation was the fact that not all participants could be interviewed. Although limited by its cross-sectional design, this study provides the opportunity for a critical look at the approaches adopted by primary health care practitioners within the framework of the Brazilian Unified Health System. As these professionals are responsible for the care of a representative portion of the Brazilian population, our findings should prompt reflection on the possibility of overtreatment, and, consequently, unnecessary resource consumption-a highly relevant issue in public health.

\section{REFERENCES}

1. Coelho LT, Silveira ADS, Lima KC, Pinheiro IVA. Cárie oclusal sem cavitação: divergências na decisão terapêutica. Odontol Clín-Científ. 2007;6(1):39-43.

2. Banerjee A. Minimal intervention dentistry: part 7. Minimally invasive operative caries management: rationale and techniques. Br Dent J. 2013;214(3):107-11. doi: 10.1038/ sj.bdj.2013.106

3. Banerjee A. "MI" caries management--an overview. Ann R Australas Coll Dent Surg. 2012;21(1):43-8.

4. Bjørndal L, Kidd EA. The treatment of deep dentine caries lesions. Dent Update. 2005;32(7):402-4.

5. Lima DC, Saliba NA, Moimaz SAS. Tratamento restaurador atraumático e sua utilização em saúde pública. RGO, Rev Gaúch Odontol. 2008;56(1):75-9.

6. Kramer PF, Cardoso L, Reis ASP, Silveira D, Tovo MF. Efeito da aplicação de selantes de fossas e fissuras na progressão de lesões cariosas oclusais em molares decíduos: observações clínicas e radiográficas. JBP Rev Ibero-Am Odontopediatr Odontol Bebê. 2003;6(34):504-14.

7. Maltz M, Garcia R, Jardim JJ, de Paula LM, Yamaguti PM, Moura MS, et al. Randomized trial of partial vs. stepwise caries removal: 3-year follow-up. J Dent Res. 2012; 91(11): 1026-31. doi: 10.1177/0022034512460403.

8. Maltz M, Jardim JJ, Mestrinho HD, Yamaguti PM, Podestá K, Moura MS, et al. Partial removal of carious dentine: a multicenter randomized controlled trial and 18-month follow-up results. Caries Res. 2013; 47(2):103-9. doi: 10.1159/000344013.

\section{CONCLUSION}

Most respondents chose invasive interventions for the majority of case vignettes involving primary teeth, even in situations in which preservation of tooth structure was recommended. Agreement across professionals was moderate, which suggests wide variability in treatment choices.

\section{Contributors}

JLS SANTOS, MF PERAZZO, GL RIBEIRO, and RT FIRMINO participated in literature review, study design, analysis and discussion of results, and contributed to the manuscript. AF GRANVILLE-GARCIA participated in data analysis and discussion and contributed to manuscript revision. JMS FERREIRA conceived and coordinated the study, participated in data analysis and discussion, and wrote and reviewed the manuscript. All listed authors contributed significantly to the study and manuscript.

9. Schwendicke F, Dörfer CE, Paris S. Incomplete caries removal: a systematic review and meta-analysis. J Dent Res. 2013;92(4):30614. doi: $10.1177 / 0022034513477425$.

10. Mialhe FL, Silva RP, Ambrosano GMB, Pereira AC, Ferreira $A C$. Detecção e tratamento de lesões cariosas oclusais entre cirurgiões-dentistas do Sistema Único de Saúde. RFO UPF. 2007;12(3):29-34.

11. Dowell TB, Holloway PJ, Keshani D, Clerehugh V. Do dentists fill teeth unnecessarily? Br Dent J. 1983;155(7):247-9.

12. Bulman JS, Osborn JF. Measuring diagnostic consistency. Br Dent J. 1989;166(10):377-81.

13. Gomez J, Ellwood RP, Martignon S, Pretty IA. Dentists' perspectives on caries-related treatment decisions. Community Dent Health. 2014;31(2):91-8.

14. Pellegrinetti MB, Imparato JCP, Raggio DPP, Politano GT, GuedesPinto AC. Avaliação do selamento de lesões de cárie em dentina de dentes decíduos. Rev Assoc Pau Cir Dent. 2009; 63(1): 2026.

15. Milgrom P. Management of patients with active caries. J Calif Dent Assoc. 2014;42(7):449-53.

16. Manton D. Partial caries removal may have advantages but limited evidence on restoration survival. Evid Based Dent. 2013;14(3):74-5.

17. Kidd EA. How 'clean' must a cavity be before restoration? Caries Res. 2004; 38 (3): 305-13. doi: 10.1159/000077770

18. Weber CM, Alves LS, Maltz M. Treatment decisions for deep carious lesions in the Public Health Service in Southern Brazil. J Public Health Dent. 2011;71(4):265-70. doi: 10.1111/j.1752-7325.2011.00258.x 
19. Ricketts D, Lamont T, Innes NP, Kidd E, Clarkson JE. Operative caries management in adults and children. Cochrane Database Syst Rev. 2013;(3):CD003808.

20. Braga MM, Mendes FM, Imparato JCP. A doença cárie dentária. In: Imparato, JPC, Raggio DP, Mendes FM. Selantes de fossas e fissuras: quando, como e por quê? São Paulo: Santos; 2008. p. 3-16.

21. Ahovuo-Saloranta A, Forss $H$, Walsh $T$, Hiiri A, Nordblad A, Mäkelä $M$, et al. Sealants for preventing dental decay in the permanent teeth. Cochrane Database Syst Rev. 2013;(3): CD001830.

22. Deery $C$. Strong evidence for the effectiveness of resin based sealants. Evid Based Dent. 2013;14(3):69-70. doi: 10.1038/ sj.ebd. 6400945 .

23. Hiiri A, Ahovuo-Saloranta A, Nordblad A, Mäkelä M. Pit and fissure sealants versus fluoride varnishes for preventing dental decay in children and adolescents. Cochrane Database Syst Rev. 2010;17;(3):CD003067.

24. Gooch BF, Griffin SO, Gray SK, Kohn WG, Rozier RG, Siegal M, et al. Preventing dental caries through school-based sealant programs: updated recommendations and reviews of evidence. J Am Dent Assoc. 2009;140(11):1356-65. doi: 10.14219/jada. archive.2009.0070

25. Bobrowski R, Schneider M. Divergência de diagnóstico entre hígido, selamento biológico e cárie oclusal em esmalte ou esmalte e dentina, realizado por acadêmicos e cirurgiõesdentistas. Stomatos. 2011;17(32):43-54

Received on: 16/9/2014 Final version resubmitted on: 17/7/2015 Approved on: 10/9/2015 